\title{
Perencanaan PLTS Rooftop untuk Kawasan Pabrik Teh PT Pagilaran Batang
}

\section{MUHAMMAD SULTHON NOVERA REGA ${ }^{1}$, NAZARUDDIN SINAGA ${ }^{2}$, JAKA WINDARTA ${ }^{3}$}

\author{
1Magister Energi, Sekolah Pascasarjana, Universitas Diponegoro \\ 2Departemen Teknik Mesin, Fakultas Teknik, Universitas Diponegoro \\ ${ }^{3}$ Departemen Teknik Elektro, Fakultas Teknik, Universitas Diponegoro \\ Email : sulthonnovera@students.undip.ac.id
}

Received 28 Mei 2021 | Revised 20 Juni 2021 | Accepted 25 Juni 2021

\begin{abstract}
ABSTRAK
Kawasan perkebunan teh PT Pagilaran Batang, Jawa Tengah memiliki nilai radiasi rata-rata 5,30 kWh/ $\mathrm{m}^{2} /$ hari sepanjang tahun 2019 dan rata-rata 4,66 kWh/ $\mathrm{m}^{2} / \mathrm{hari}$ dalam rentang 1997-2019. Konsumsi beban listrik PT Pagilaran secara keseluruhan adalah sebesar 2.853.919,89 kWh/tahun. Khusus untuk konsumsi beban listrik pabrik produksi dan pengolahan adalah sebesar 657.104,90 kWh/tahun dengan sumber listrik konvensional PLN. Penelitian ini bertujuan untuk mendesain dan mengetahui unjuk kerja potensi energi listrik yang dapat dihasilkan PLTS rooftop menggunakan simulasi HelioScope sebagai rekomendasi penggunaan energi terbarukan. Dari hasil simulasi diperoleh potensi energi listrik yang dapat dihasilkan oleh PLTS rooftop adalah 629.840,80 kWh/tahun yang dapat memenuhi 95,85\% kebutuhan beban listrik untuk pabrik produksi dan pengolahan teh dengan rasio kinerja sebesar $77,5 \%$.
\end{abstract}

Kata kunci: HelioScope, Photovoltaic, PLTS Rooftop, Rasio Kinerja, Tenaga Surya

\begin{abstract}
The tea plantation area of PT Pagilaran Batang, Central Java has an average radiation value of $5.30 \mathrm{kWh} / \mathrm{m}^{2} /$ day throughout 2019 and an average of 4.66 $\mathrm{kWh} / \mathrm{m}^{2} /$ day in the span of 1997-2019. The electrical load consumption of PT Pagilaran is 2,853,919.89 kWh/year. Specifically for the electrical load consumption in the tea production and processing plants is $657,104.90 \mathrm{kWh} /$ year with conventional electricity source from PLN. This study aims to design and determine the potential solar rooftop performance assessment of electrical energy that could be generated using the HelioScope simulation as the recommendation for applying renewable energy. Based on the simulation result, the potential of electrical energy that can be generated by PLTS rooftop is $629,840.80 \mathrm{kWh} /$ year which could meet $95.85 \%$ of the electrical load consumption for the tea production and processing plants with performance ratio of $77.5 \%$.
\end{abstract}

Keywords: HelioScope, Photovoltaic, Solar Rooftop, Performance Ratio, Solar Power 


\section{PENDAHULUAN}

Indonesia berada di zona khatulistiwa dengan sinar matahari yang melimpah tiap harinya. Potensi sinar matahari yang dapat dimanfaatkan untuk Pembangkit Listrik Tenaga Surya (PLTS) di Indonesia rata-rata sebesar $4,8 \mathrm{kWh} / \mathrm{m}^{2} / \mathrm{hari}$, atau dikenal sebagai potensi radiasi sinar matahari (Winardi, dkk, 2019) atau dalam istilah ilmiah adalah insolation. Potensi tenaga surya secara nasional $4,8 \mathrm{kWh} / \mathrm{m}^{2} /$ hari tersebut setara dengan $207.898 \mathrm{MW}$, namun baru dimanfaatkan sebesar 0,05\% alias 100 MW saja (Dewan Energi Nasional, 2020). Sumber energi dari matahari menjadi salah satu pilihan alternatif karena ketersediaannya yang cukup melimpah dan memiliki tingkat pencemaran yang lebih rendah daripada pembangkit listrik yang bersumber dari energi fosil (Yakin \& Rajagukguk, 2020). Hal tersebut yang membuat teknologi sistem photovoltaic menjadi salah satu teknologi energi terbarukan yang diminati di dunia (Hernández-Callejo, dkk, 2019). Berdasarkan teknologi yang digunakan, PLTS terbagi menjadi dua sistem, yaitu standalone dan on-grid (Rizkasari, dkk, 2020). Standalone di sini biasa disebut juga sebagai off-grid atau tidak terhubung ke jaringan listrik PT PLN (Persero), yang biasanya dirancang untuk memanfaatkan sinar matahari secara mandiri pada daerah yang terisolasi, pedalaman, atau pulau-pulau yang belum terhubung dengan sistem transmisi dan distribusi PLN. Sedangkan sistem on-grid adalah sebaliknya, yaitu terhubung dengan jaringan listrik PLN.

Manfaat dari PLTS on-grid adalah keandalannya yang lebih tinggi dibandingkan dengan offgrid, karena terdapat dua sumber energi listrik yang dapat saling menyokong satu sama lain. PLTS on-grid yang sedang digalakkan oleh pemerintah adalah PLTS atap atau rooftop. PLTS rooftop merupakan salah satu solusi untuk pemanfaatan energi terbarukan di kawasan industri, perumahan, dan perkantoran, yang dinilai memiliki lahan terbatas. Kementerian Energi dan Sumber Daya Mineral (ESDM) Republik Indonesia telah mengatur kebijakan terkait energi terbarukan yaitu Peraturan Menteri ESDM Nomor 4 Tahun 2020 tentang Pemanfaatan Sumber Energi Terbarukan Untuk Penyediaan Tenaga Listrik. Selain itu, terdapat Peraturan Menteri ESDM Nomor 4 Tahun 2012 tentang Harga Pembelian Tenaga Listrik oleh PT PLN (Persero) dari Pembangkit Tenaga Listrik yang menggunakan Energi Terbarukan Skala Kecil dan Menengah atau Kelebihan Tenaga Listrik serta spesifik pada Peraturan Menteri ESDM Nomor 19 Tahun 2016 tentang Pembelian Tenaga Listrik dari Pembangkit Listrik Tenaga Surya oleh PT PLN (Persero) (Wijoyo \& Halim, 2018). Payung hukum dan kebijakan ini diharapkan dapat menarik calon investor maupun pelanggan untuk memasang photovoltaic, khususnya PLTS rooftop di gedung-gedung, bangunan, maupun rumah mereka. Pada tahun 2025, pemerintah menargetkan kapasitas PLTS terpasang sebesar 6,5 GW untuk mencapai target Rencana Umum Energi Nasional (RUEN) (Dewan Energi Nasional, 2020). Artinya, manuver kebijakan yang pemerintah lakukan adalah upaya untuk mendorong penggunaan Energi Baru dan Terbarukan (EBT), khususnya di bidang energi surya.

Pemerintah Indonesia juga telah menandatangani Paris Agreement to the United Nations Framework Convention on Climate Change (Persetujuan Paris atas Konvensi Kerangka Kerja Perserikatan Bangsa-Bangsa mengenai Perubahan Iklim) pada tanggal 22 April 2016 di New York, Amerika Serikat (Arinaldo, dkk, 2019). Dengan berpartisipasinya Indonesia dalam Paris Agreement, pemerintah telah berkomitmen untuk mengembangkan EBT sekaligus mengurangi tingkat emisi dari berbagai sektor. PT Pagilaran sebagai pabrik yang berkaitan erat dengan alam memiliki potensi energi surya yang melimpah, namun belum memanfaatkan potensi tersebut. Penelitian ini bertujuan untuk mendesain serta mengetahui performa PLTS rooftop, seperti nilai rugi-rugi, nilai rasio kinerja, dan nilai Total Solar Resource Fraction(TSRF) akan potensi energi listrik yang dapat diproduksi menggunakan simulasi HelioScope sebagai rekomendasi penggunaan energi surya melalui teknologi PLTS rooftop di kawasan pabrik. 
Faktor-faktor yang dapat mempengaruhi efisiensi dalam produksi energi listrik menggunakan PLTS adalah nilai radiasi matahari, temperatur sel atau modul surya, orientasi modul surya serta derajat kemiringannya, dan pengaruh bayangan atau shading yang terjadi selama waktu pengoperasian (Yakin \& Rajagukguk, 2020) (Ariani \& Winardi, 2014). Besarnya daya yang dihasilkan tergantung pada nilai radiasi matahari dan nilai temperatur pada modul surya, karena akan mempengaruhi besarnya arus dan tegangan yang dihasilkan (Wicaksena \& Winardi, 2017). Sedangkan besarnya bayangan akan mempengaruhi total radiasi yang akan diterima oleh modul surya pada proses pembangkitan energi listrik. Pertimbanganpertimbangan ini akan digunakan sebagai data masukan simulasi HelioScope untuk mengetahui performa PLTS rooftop yang dirancang.

\section{METODE}

Gambar 1 menunjukkan diagram alir penelitian dengan data masukan adalah nilai radiasi matahari dan konsumsi energi listrik pada PT Pagilaran. Lalu, dilakukan observasi lapangan untuk mengetahui bentuk aktual bangunan. Setelah mengetahui bentuk aktual bangunan, khususnya atap pabrik, dilakukan proses simulasi desain PLTS menggunakan HelioScope dan analisis evaluasi perancangannya. Dari hasil analisis, selanjutnya dilakukan finalisasi dan penarikan kesimpulan dari data yang telah diolah.

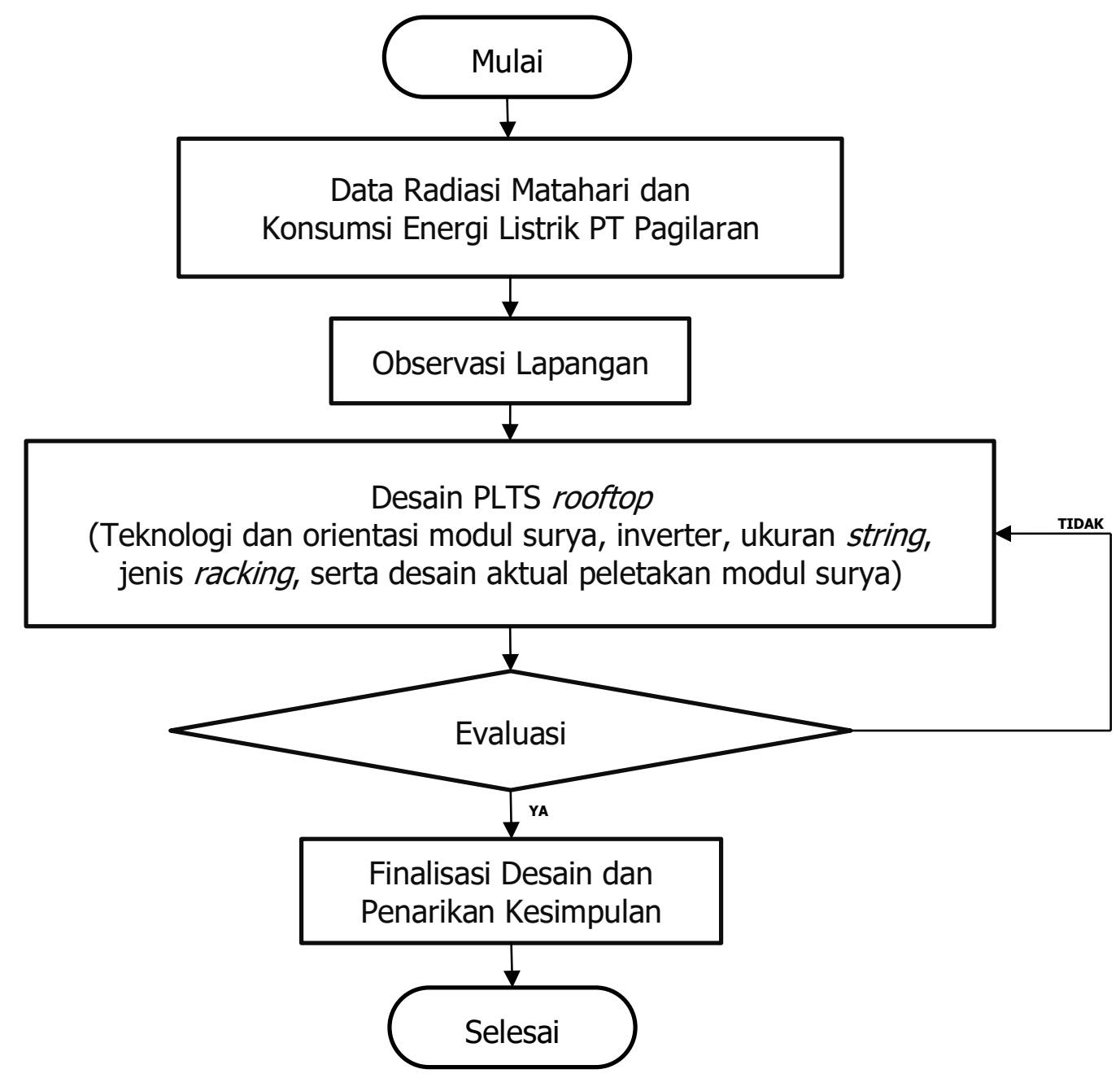

Gambar 1. Diagram Alir Penelitian Desain PLTS Rooftop Kawasan Pabrik PT Pagilaran 


\subsection{Studi Pustaka}

Awal penelitian dilakukan studi pustaka terkait teknologi PLTS rooftop serta pencarian data untuk mengetahui kebutuhan beban listrik di PT Pagilaran Batang, Jawa Tengah serta mengetahui data cuaca dan nilai radiasi matahari rata-rata pada kawasan PT Pagilaran. Tabel 1 menunjukkan nilai radiasi matahari rata-rata pada lokasi penelitian sepanjang tahun 2019 adalah 5,30 kWh/m²/hari yang disadur dari laman National Aeronautics and Space Administration (NASA). Sedangkan berdasarkan penelitian Aspriadi (Aspriadi, dkk, 2019) total konsumsi energi listrik eksisting pada kawasan PT Pagilaran yang meliputi konsumsi pabrik, kantor, fasilitas pendukung, kawasan agrowisata, dan penerangan jalan sebesar 2.853.919,89 kWh/tahun. Khusus untuk konsumsi energi listrik kawasan pabrik teh adalah sebesar 657.104,90 kWh/tahun.

Tabel 1. Data Radiasi Matahari pada Kawasan PT Pagilaran Batang 2019 (NASA, 2021)

\begin{tabular}{|c|c|}
\hline Bulan & $\begin{array}{c}\text { Radiasi Matahari } \\
\text { (kWh/ } \mathbf{~} \mathbf{~} \mathbf{h a r i})\end{array}$ \\
\hline Januari & 4,85 \\
\hline Februari & 5,22 \\
\hline Maret & 4,60 \\
\hline April & 5,16 \\
\hline Mei & 5,26 \\
\hline Juni & 4,93 \\
\hline Juli & 5,06 \\
\hline Agustus & 5,53 \\
\hline September & 6,01 \\
\hline Oktober & 6,15 \\
\hline November & 5,66 \\
\hline Desember & 5,18 \\
\hline Rata-rata & $\mathbf{5 , 3 0}$ \\
\hline
\end{tabular}

Gambar 2 menunjukkan peta potensi data radiasi sepanjang 1997 - 2019 di pulau Jawa dengan lokasi titik penelitian ditandai oleh simbol huruf "P". Data radiasi matahari di kawasan PT Pagilaran selama 22 tahun tersebut bernilai $4,66 \mathrm{kWh} / \mathrm{m}^{2} / \mathrm{hari}$. Ini artinya nilai rata-rata radiasi matahari pada tahun 2019 lebih tinggi daripada nilai rata-rata sepanjang 1997 - 2019, yaitu $5,30 \mathrm{kWh} / \mathrm{m}^{2} /$ hari.

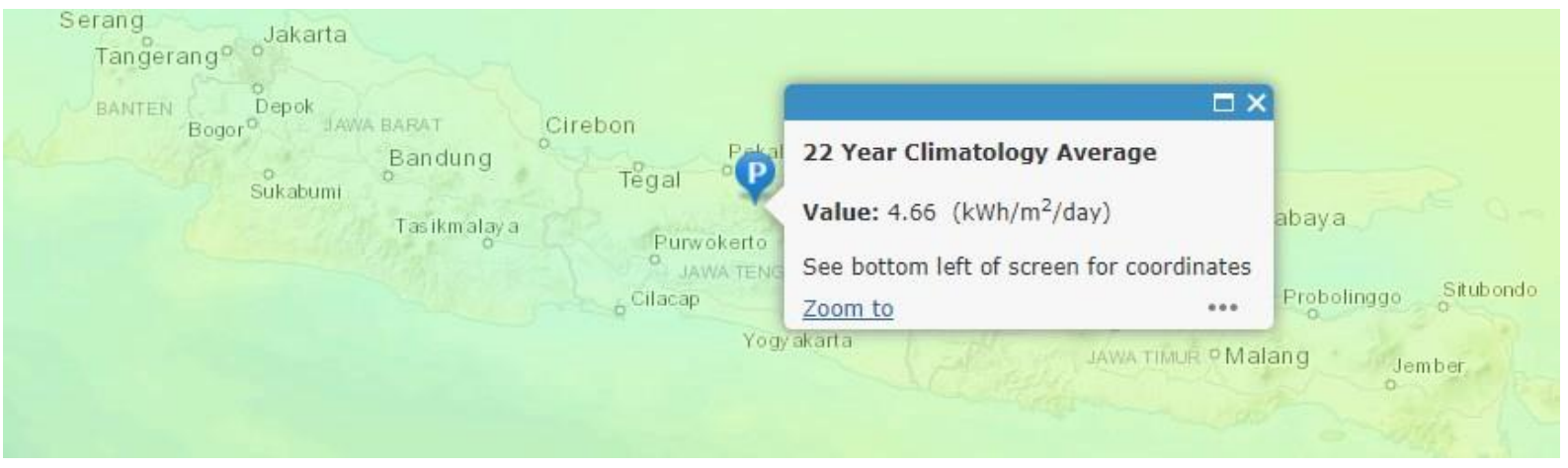

Gambar 2. Data Radiasi Matahari Matahari pada Kawasan PT Pagilaran Batang 1997-2019 (NASA, 2021) 


\subsection{Observasi Lokasi}

Setelah mengetahui potensi data radiasi matahari pada lokasi penelitian, kemudian dilakukan observasi untuk mengetahui kondisi bangunan dan bentuk aktual rooftop. Lokasi penelitian terletak pada latitude -7,11126855245 dan longitude 109,853033844, Desa Keteleng, Kecamatan Blado, Kabupaten Batang, Jawa Tengah. Akses jalan utama menuju ke PT Pagilaran adalah sebesar 35 km dari ibukota Kabupaten Batang, 45 km dari Kota Pekalongan, dan $115 \mathrm{~km}$ dari Kota Semarang. Pengamatan pada lokasi diperlukan mengingat untuk mendesain PLTS harus mempertimbangkan kondisi aktual, seperti efek shading baik dari faktor konstruksi bangunan maupun lingkungan sekitar. Efek shading ini akan berimbas pada nilai radiasi matahari yang akan diterima oleh modul surya, sehingga kinerja PLTS tidak optimal. Gambar 3 memperlihatkan tampak aerial pabrik teh PT Pagilaran yang didapatkan melalui bantuan citra satelit GoogleMaps.

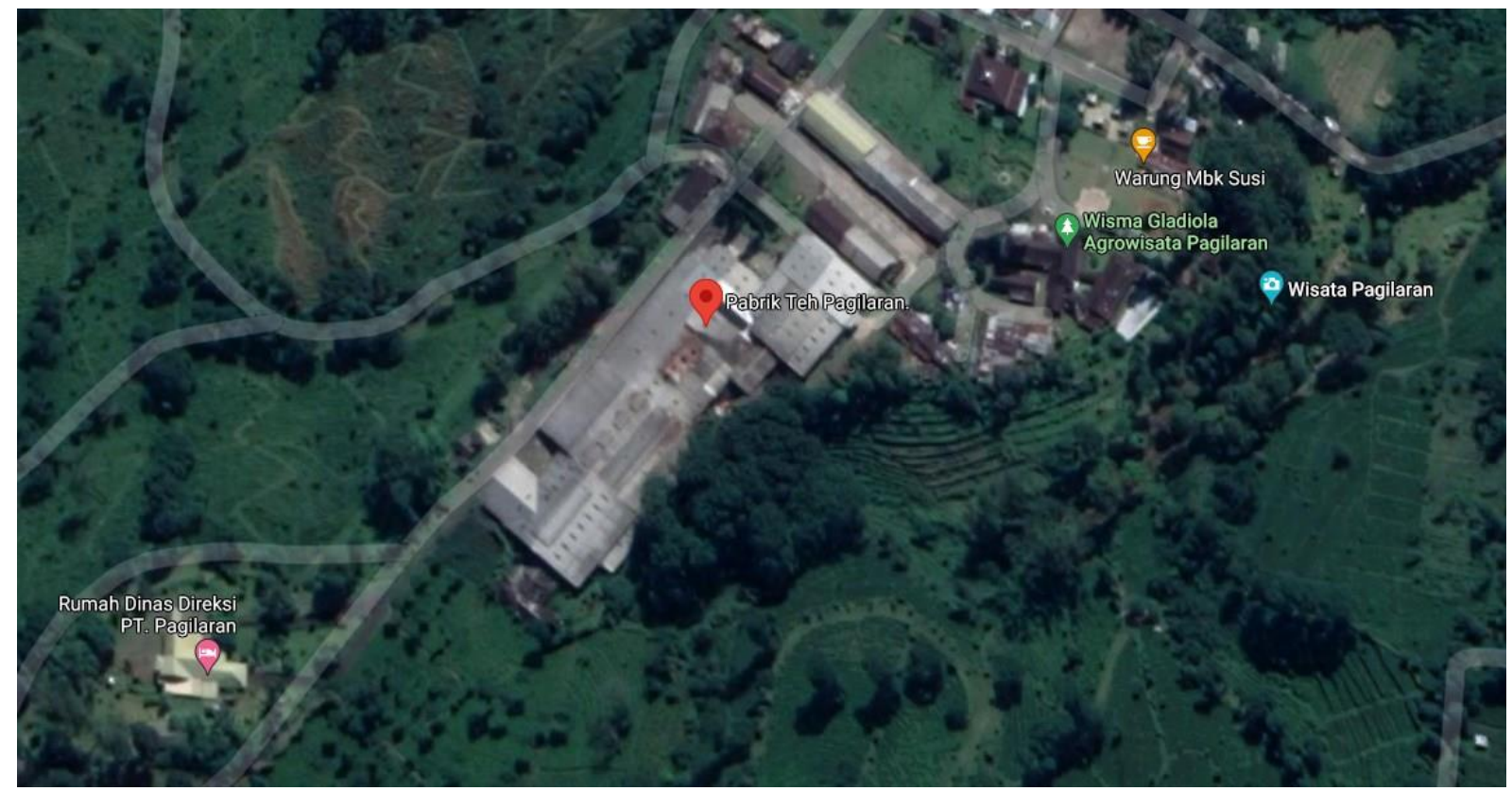

Gambar 3. Tampak Aerial Lokasi Pabrik Teh PT Pagilaran

\subsection{Simulasi HelioScope}

Simulasi pada penelitian ini dibantu oleh HelioScope. HelioScope adalah web-based simulation atau simulasi berbasis web untuk membantu para insinyur atau desainer dalam melakukan perencanaan atau mendesain PLTS (Umar, dkk, 2018). Dalam mendesain PLTS rooftop PT Pagilaran, terdapat data masukan pada simulasi HelioScope yang harus dipenuhi. Beberapa data masukan pada HelioScope yang menjadi dasar simulasi adalah titik koordinat lokasi PLTS rooftop yang akan dipasang, pemilihan teknologi modul surya dan jenisnya, serta pemilihan jenis inverter. Pada simulasi penelitian ini juga dilakukan desain gambar PLTS rooftop, pemilihan ukuran string, pemilihan jenis racking dan orientasi modul surya, serta rasio DC/AC atau rasio dari kapasitas photovoltaic array terhadap kapasitas inverter terpasang yang akan berpengaruh terhadap clipping loss. Peletakan modul surya pada atap PT Pagilaran mempertimbangkan luasan atap dan arah kedatangan matahari sehingga didapatkan jumlah modul surya yang optimal terhadap segmentasi luasan atap. Beberapa perhitungan di HelioScope antara lain adalah perhitungan Inverter Load Ratio, Performance Ratio, nilai Total Solar Resource Fraction, nilai kWh/kWp, serta nilai pemenuhan kebutuhan beban oleh energi listrik yang dihasilkan oleh PLTS rooftop. Sedangkan, beberapa simulasi lainnya seperti rugi- 
rugi akibat pengkabelan, ketidakcocokan modul atau mismatch, rugi-rugi akibat refleksi dan efek shading didapatkan dari perkiraan sesuai datasheet yang digunakan.

Persamaan (1) menunjukkan perhitungan Inverter Load Ratio (ILR) yang ditentukan oleh kapasitas DC yang diwakili oleh PV array terhadap kapasitas AC yang diwakili oleh inverter terpasang.

$$
I L R=\frac{D C \text { Nameplate }}{\text { AC Nameplate }}
$$

Persamaan (2) menunjukkan perhitungan Performance Ratio (PR) atau rasio kinerja yang merupakan persentase dari total potensi energi PV array yang dapat dikonversikan menjadi energi listrik dalam bentuk arus listrik bolak-balik.

$$
P R=\frac{\text { Energy to Grid }(\text { Wh })}{\text { POA Irradiance }\left(\frac{W h}{m^{2}}\right) \times \frac{D C N a m e p l a t e(W)}{\operatorname{STC}\left(1000 W / m^{2}\right)}}
$$

Persamaan (3) menunjukkan perhitungan Total Solar Resource Fraction (TSRF), yaitu jumlah sinar matahari terukur pada suatu area yang menerimanya selama setahun. TSRF juga merupakan perbandingan insolation yang ada, termasuk efek shading dan Tilt and Orientation Factor (TOF) terhadap total insolation pada suatu lokasi dengan kemiringan optimal dan orientasi optimal yang membuat tidak adanya rugi-rugi bayangan. Nilai TSRF $100 \%$ sangat jarang ditemukan karena terdapat pepohonan dan faktor lainnya yang membuat bayangan. Solar Access pada perhitungan TSRF ditunjukkan oleh Persamaan (4).

$$
\begin{aligned}
& \text { TSRF }=\frac{\text { TOF }}{\text { Solar Access }} \times 100 \% \\
& \text { Solar Access }=\frac{\text { Shaded Irradiance }}{\text { POA Irradiance }}
\end{aligned}
$$

Persamaan (5) menunjukkan perhitungan nilai $\mathrm{kWh} / \mathrm{kWp}$ yang merupakan total energi yang mampu dibangkitkan terhadap kapasitas DC dari PV array dalam setahun.

$$
k W h / k W p=\frac{\text { Energy to Grid }(W h)}{D C \text { Nameplate }(W p)}
$$

\subsection{Analisis Hasil Perancangan}

Dari hasil simulasi kemudian dilakukan analisis data hasil produksi energi listrik tahunan untuk selanjutnya ditarik kesimpulan. Hasil simulasi telah memuat laporan nilai-nilai efek shading, pengkabelan, efisiensi komponen, ketidakcocokan modul, serta rekomendasi untuk peletakan susunan modul panel surya dan konfigurasinya berdasarkan desain yang telah dibuat. Energi listrik yang dapat dihasilkan oleh PLTS rooftop selanjutnya dikomparasi dengan jumlah konsumsi energi listrik tahunan pada kawasan pabrik PT Pagilaran yang bersumber dari listrik PLN, sehingga didapatkan persentase energi listrik yang mampu disuplai oleh PLTS rooftop. Selain itu, total simulasi rugi-rugi, nilai rasio kinerja, dan nilai TSRF juga disajikan sebagai data pendukung untuk memperkuat perencanaan. 


\section{HASIL SIMULASI DAN PEMBAHASAN}

\subsection{Sistem PLTS Rooftop PT Pagilaran}

Luas kawasan PT Pagilaran adalah 4.700 ha (Aspriadi, dkk, 2019) dengan luas kawasan pabrik tehnya adalah $17.548,31 \mathrm{~m}^{2}$. Dari luas area pabrik, luasan atap yang memungkinkan untuk disimulasikan menjadi PLTS rooftop adalah sebesar $6.460,2 \mathrm{~m}^{2}$. Berdasarkan hasil observasi lokasi, instalasi PLTS rooftop ini akan dibagi menjadi enam belas segmentasi, dikarenakan oleh konstruksi atap bangunan yang tidak seragam atau uniform. Enam belas segmentasi atap beserta luasannya, jumlah modul terpasang tiap segmen, kapasitas terpasang tiap segmen, serta tipe mounting modul surya dan orientasinya dapat dilihat pada Tabel 2. Mounting yang digunakan adalah tipe flush mount, yaitu jenis pemasangan modul surya yang cocok dan biasa digunakan pada atap yang memiliki slope atau tingkat kemiringan (QuickMount PV, 2020). Segmentasi atap pada field segment 6 memiliki potensi luasan atap paling besar, $1.648,7 \mathrm{~m}^{2}$, sehingga jumlah modul terpasang pada area tersebut berjumlah paling banyak, yaitu 475 modul surya. Sedangkan field segment 15 memiliki potensi luasan atap paling kecil, 64,2 $\mathrm{m}^{2}$, sehingga hanya tujuh modul surya saja yang dapat terpasang. Untuk orientasi modul surya disesuaikan dengan bentuk atap dan arah terhadap kedatangan matahari. Dari enam belas segmentasi atap, hanya dua segmen yang orientasi modul suryanya adalah horizontal, yaitu field segment 13 dan 14.

Tabel 2. Segmentasi Atap untuk PLTS Rooftop Pabrik Teh PT Pagilaran

\begin{tabular}{|c|c|c|c|}
\hline Segmen & Luasan Atap $\left(\mathrm{m}^{2}\right)$ & Jumlah Modul & $\begin{array}{l}\text { Tipe Mounting dan } \\
\text { Orientasi Modul }\end{array}$ \\
\hline Field Segment 1 & 255,6 & 58 & Flush Mount - Vertikal \\
\hline Field Segment 2 & 409,8 & 82 & Flush Mount - Vertikal \\
\hline Field Segment 3 & 292,4 & 72 & Flush Mount - Vertikal \\
\hline Field Segment 4 & 418,2 & 119 & Flush Mount - Vertikal \\
\hline Field Segment 5 & 300,1 & 80 & Flush Mount - Vertikal \\
\hline Field Segment 6 & $1.648,7$ & 475 & Flush Mount - Vertikal \\
\hline Field Segment 7 & 219,7 & 45 & Flush Mount - Vertikal \\
\hline Field Segment 8 & 262,8 & 69 & Flush Mount - Vertikal \\
\hline Field Segment 9 & 509,4 & 138 & Flush Mount - Vertikal \\
\hline Field Segment 10 & 82,8 & 14 & Flush Mount - Vertikal \\
\hline Field Segment 11 & 712,2 & 198 & Flush Mount - Vertikal \\
\hline Field Segment 12 & 176,0 & 26 & Flush Mount - Vertikal \\
\hline Field Segment 13 & 124,4 & 13 & Flush Mount - Horizontal \\
\hline Field Segment 14 & 474,2 & 108 & Flush Mount - Horizontal \\
\hline Field Segment 15 & 64,2 & 7 & Flush Mount - Vertikal \\
\hline Field Segment 16 & 509,7 & 124 & Flush Mount - Vertikal \\
\hline Total & $6.460,2$ & 1.628 & \\
\hline
\end{tabular}

Modul surya yang dipilih dalam desain PLTS rooftop PT Pagilaran adalah TSM-PD14 320, Trina Solar dengan spesifikasi dan karakteristik yang dapat dilihat pada Tabel 3. STC adalah standard test condition dan NOCT merupakan nominal operating cell temperature. STC sendiri merupakan kondisi pengujian pada irradiance $1.000 \mathrm{~W} / \mathrm{m}^{2}$ dan pada kondisi temperatur sel $25^{\circ} \mathrm{C}$ dengan toleransi pengukuran $3 \%$. Sedangkan NOCT merupakan kondisi pengujian pada irradiance $800 \mathrm{~W} / \mathrm{m}^{2}$ dengan temperatur lingkungan $20^{\circ} \mathrm{C}$ dan kondisi kecepatan angin $1 \mathrm{~m} / \mathrm{s}$. Teknologi yang digunakan adalah Si-Poly 72 sel multikristalin. Efisiensi modul surya yang diklaim oleh Trina Solar adalah 16,5\%. Efisiensi ini sudah baik dibandingkan modul surya pada umumnya yang berkisar antara 10-15\%. Di dalam penelitian Ilyas (Ilyas \& Kasim, 2017), 
efisiensi modul surya yang diintegrasikan dengan reflektor parabola hanya meningkat 1,039 kali daripada efisiensi referensinya saja, yang semula $10,71 \%$ menjadi $11,13 \%$.

Tabel 3. Spesifikasi Modul Surya TSM-PD14 320

\begin{tabular}{|c|c|c|}
\hline Electrical Data & STC & NOCT \\
\hline Peak Power Watts - PMax $_{\text {Maximum Power Voltage - V }}$ & $320 \mathrm{Wp}$ & $237 \mathrm{Wp}$ \\
\hline Maximum Power Current- IMPP & $37,1 \mathrm{~V}$ & $34,3 \mathrm{~V}$ \\
\hline Open Circuit Voltage - Voc & $8,63 \mathrm{~A}$ & $6,92 \mathrm{~A}$ \\
\hline Short Circuit Current - Isc & $45,5 \mathrm{~V}$ & $42,1 \mathrm{~V}$ \\
\hline
\end{tabular}

Gambar 4 menunjukkan kurva karakteristik tegangan terhadap daya yang dihasilkan oleh modul TSM-PD14 320 dan Gambar 5 menunjukkan kurva karakteristik tegangan terhadap arus yang dihasilkan oleh modul TSM-PD14 320. Semakin besar nilai irradiance matahari, daya, tegangan, dan arus listrik maksimal juga akan semakin besar.

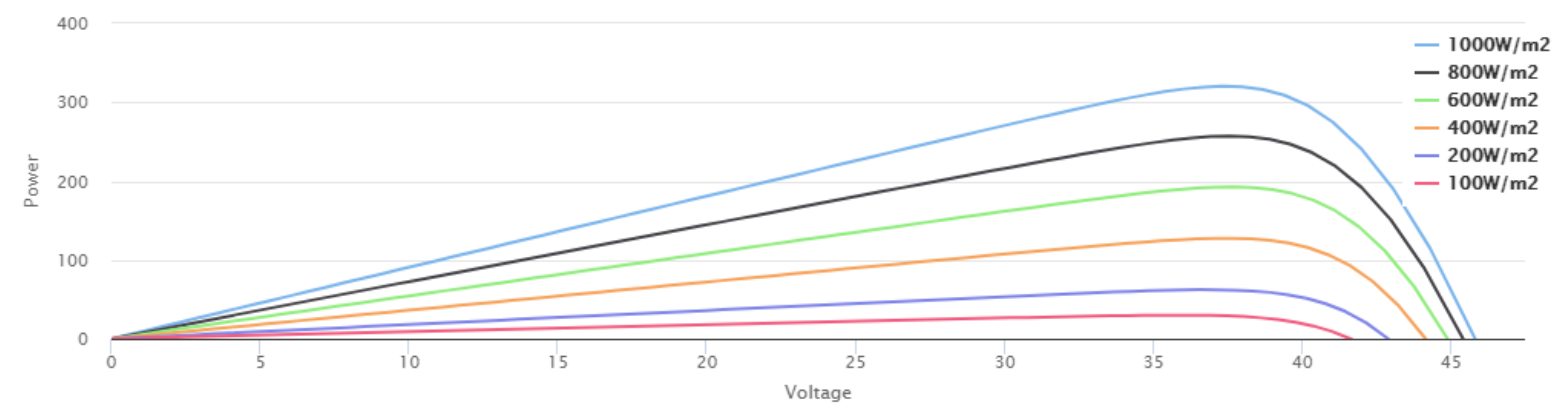

Gambar 4. Kurva Tegangan terhadap Daya yang Dihasilkan Modul Surya TSM-PD14 320

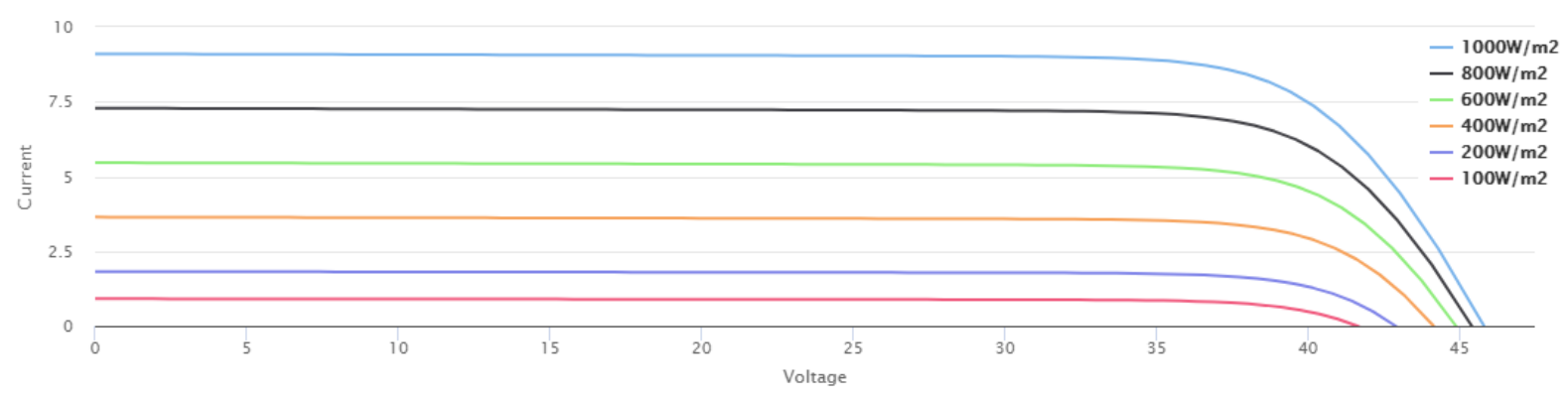

Gambar 5. Kurva Tegangan terhadap Arus yang Dihasilkan Modul Surya TSM-PD14 320

Inverter yang dipilih adalah SMA Sunny Tripower 24000TL-US. Spesifikasi inverter dapat dilihat pada Tabel 4. Inverter dengan manufaktur pengembang SMA memiliki produksi energi dengan tingkat efisiensi yang tinggi, fleksibilitas desain yang baik, dan memiliki tingkat kompatibilitas yang tinggi dengan beragam teknologi modul surya (Rizkasari, dkk, 2020). Berdasarkan datasheet kurva efisiensi CEC atau California Energy Commission (SMA, 2018), efisiensi inverter adalah sebesar 98\%, dengan efisiensi maksimumnya adalah 98,5\%. Nilai nominal daya listriknya adalah $24 \mathrm{~kW}$ dengan arus maksimal sebesar $29 \mathrm{~A}$ dan nilai tegangan DC 
masukan maksimal adalah $1 \mathrm{kV}$. Nilai harmonisa oleh inverter SMA Sunny Tripower 24000TLUS sesuai datasheet adalah sebesar 3\%.

Tabel 4. Spesifikasi Inverter SMA Sunny Tripower 24000TL-US

\begin{tabular}{|c|c|}
\hline Karakteristik & Nilai \\
\hline AC Nominal Power Output & $24 \mathrm{~kW}$ \\
\hline Maximum DC Input Voltage & $1.000 \mathrm{~V}$ \\
\hline Minimum DC Voltage / Start Voltage & $150 \mathrm{~V} / 188 \mathrm{~V}$ \\
\hline Maximum MPPT Voltage & $800 \mathrm{~V}$ \\
\hline Minimum MPPT Voltage & $150 \mathrm{~V}$ \\
\hline Maximum Output Current & $29 \mathrm{~A}$ \\
\hline Harmonics & $<3 \%$ \\
\hline
\end{tabular}

\subsection{Hasil Simulasi HelioScope}

Setelah data masukan lengkap, dilakukan simulasi menggunakan HelioScope. Yang pertama dilakukan adalah memetakan PLTS sesuai segmentasinya yang dapat dilihat pada Gambar 6. Simulasi ini dilakukan dengan mempertimbangkan kondisi aktual, sehingga dapat dilihat pada Gambar 7, tampak 3D desain PLTS rooftop beserta dengan efek shading atau efek bayangan dan orientasi modul surya yang dipilih. Pemilihan orientasi modul surya horizontal atau vertikal dilakukan dengan pertimbangan kondisi bangunan terhadap arah kedatangan matahari dan luasan atap. Photovoltaic array memiliki arus jenis DC, maka diperlukan inverter untuk mengubah sumber DC menjadi AC supaya dapat digunakan oleh konsumsi beban listrik. Perbandingan DC terhadap AC (ILR) yang baik memiliki aturan maksimum perbandingan sebesar 1,25 dengan tujuan untuk meminimalkan rugi-rugi akibat oversizing photovoltaic array atau dikenal sebagai over-power clipping losses (Folsom Labs, 2016). Rugi-rugi ini akan terjadi apabila perbandingan antara DC terhadap AC memiliki nilai yang tinggi. Memang, apabila nilai perbandingan DC terhadap AC tinggi tidak akan berpengaruh pada tingkat irradiance yang rendah (Pandey, dkk, 2019). Namun, mengingat faktor efisiensi dan finansial, nilai ILR akan dipertimbangkan. Inverter yang digunakan adalah SMA Sunny Tripower 24000TL-US dengan total kapasitas AC nameplate sebesar 457,1 kW. Sehingga didapatkan ILR atau perbandingan daya DC terhadap AC sebesar 1,14 dengan total inverter adalah Sembilan belas buah.

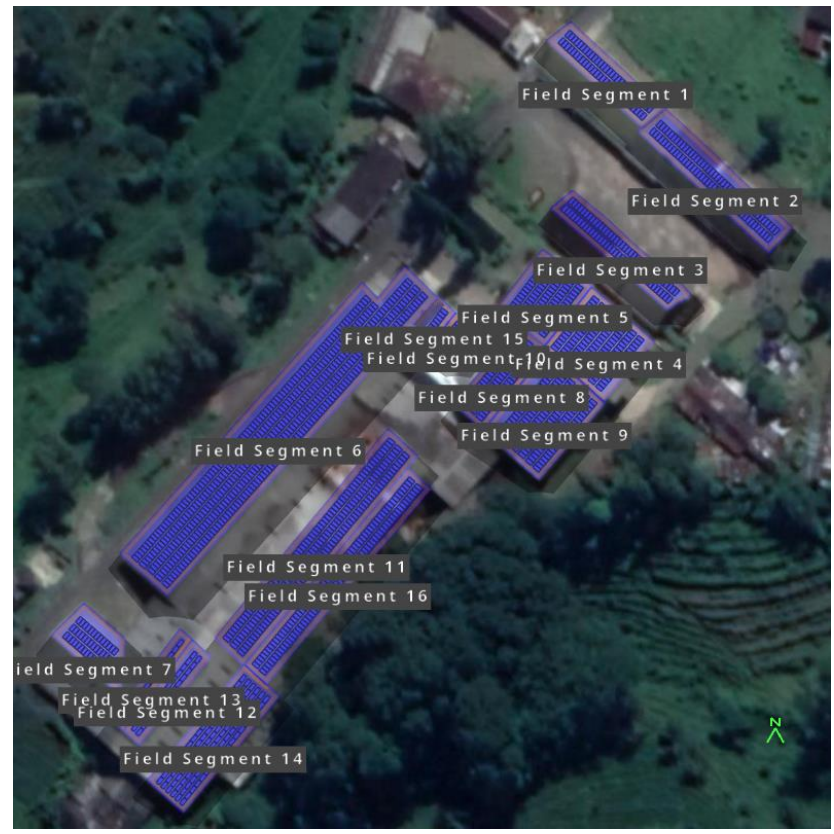

Gambar 6. Pembagian Segmentasi Atap PT Pagilaran dengan HelioScope

$$
\text { ELKOMIKA - } 896
$$




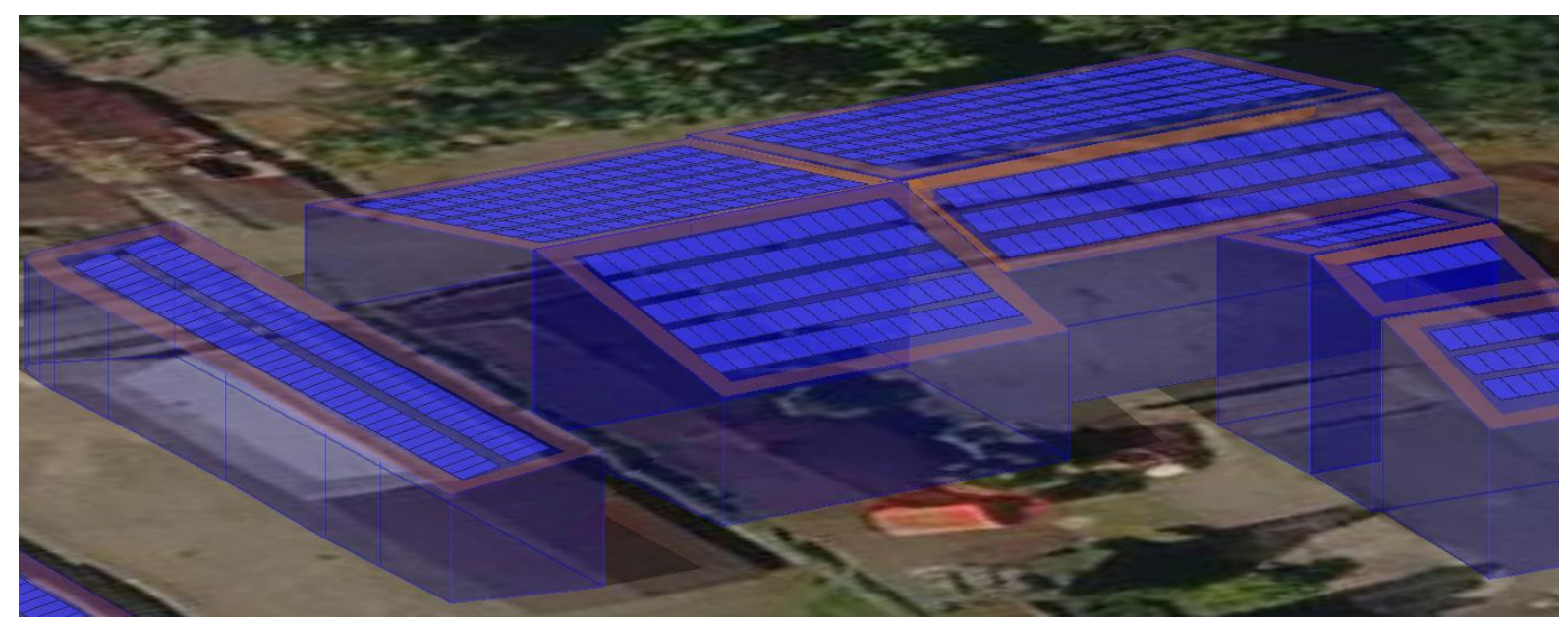

Gambar 7. Tampak Pemodelan 3D Penempatan PLTS pada Pabrik Teh PT Pagilaran

Desain PLTS rooftop PT Pagilaran mampu menghasilkan kapasitas photovoltaic array sebesar $521,0 \mathrm{kWp}$ dengan total 1.628 unit modul surya yang terhubung dengan jaringan PLN untuk menyuplai kebutuhan beban listrik yang berada dalam area pabrik. Selanjutnya, dalam menentukan jumlah photovoltaic string harus memenuhi syarat tegangan pengoperasian modul surya berdasarkan datasheet, yaitu dalam rentang $150 \mathrm{~V}$ hingga $800 \mathrm{~V}$. $\mathrm{V}_{\mathrm{MP}}$ dan $\mathrm{V}_{\mathrm{OC}}$ tidak boleh kurang atau melebihi batas minimum dan batas maksimum. String sizing dalam perancangan sistem PLTS PT Pagilaran adalah rentang 14 modul surya hingga 17 modul surya, yang berada dalam batas aman pengoperasian untuk dihubungkan ke dalam inverter. SingleLine-Diagram (SLD) sistem PLTS rooftop PT Pagilaran dapat dilihat pada Gambar 8. Pada SLD tersebut dapat terlihat proses konversi energi matahari menjadi energi listrik dimulai dari 1.628 modul surya yang kemudian terkelompok dalam beberapa string dengan ukuran string antara 14 - 17 yang masih masuk kriteria pengoperasian modul surya sesuai datasheet. Selanjutnya, tiap-tiap string terhubung dengan circuit combiner box yang merupakan tempat proteksi arus DC, hingga akhirnya terkoneksi menuju sembilan belas inverter untuk diubah menjadi listrik AC sebelum menuju beban listrik.

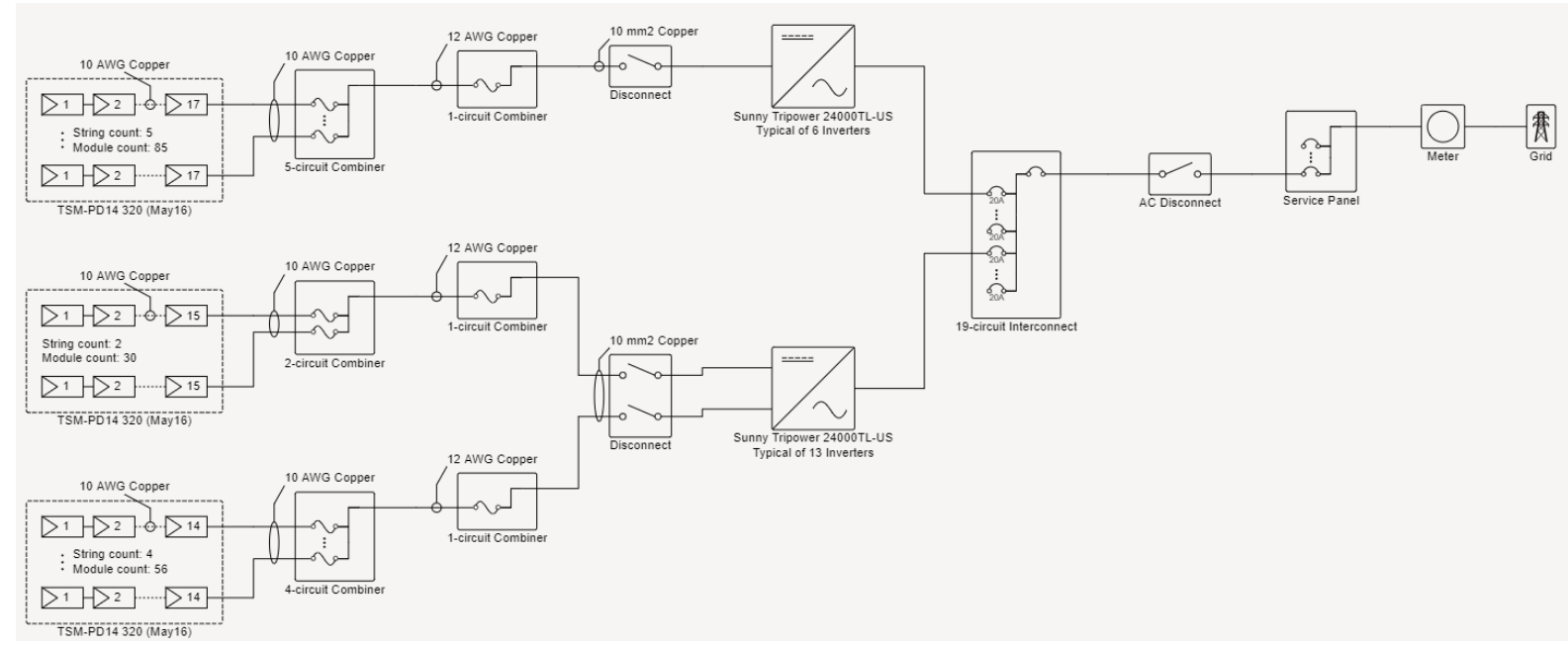

Gambar 8. Desain Single-Line-Diagram Sistem PLTS Rooftop PT Pagilaran 
Dari Tabel 5, dapat dilihat bahwa segmen 6 memiliki kapasitas paling besar yaitu $152 \mathrm{kWp}$ dan kapasitas paling kecil berada pada segmen segmen 15 dengan 2,24 kWp. Hal ini linier dengan jumlah modul surya yang terpasang.

Tabel 5. Segmentasi Atap untuk PLTS Rooftop Pabrik Teh PT Pagilaran

\begin{tabular}{|c|c|}
\hline Segmen & Kapasitas Terpasang (kWp) \\
\hline Field Segment 1 & 18,6 \\
\hline Field Segment 2 & 26,2 \\
\hline Field Segment 3 & 23,0 \\
\hline Field Segment 4 & 38,1 \\
\hline Field Segment 5 & 25,6 \\
\hline Field Segment 6 & 152,0 \\
\hline Field Segment 7 & 14,4 \\
\hline Field Segment 8 & 22,1 \\
\hline Field Segment 9 & 44,1 \\
\hline Field Segment 10 & 4,48 \\
\hline Field Segment 11 & 63,4 \\
\hline Field Segment 12 & 8,32 \\
\hline Field Segment 13 & 4,16 \\
\hline Field Segment 14 & 34,6 \\
\hline Field Segment 15 & 2,24 \\
\hline Field Segment 16 & 39,7 \\
\hline Total & $\mathbf{5 2 1 , 0}$ \\
\hline
\end{tabular}

Simulasi akhir dalam HelioScope adalah hasil laporan perkiraan potensi energi listrik dalam setahun yang dapat dihasilkan oleh sistem PLTS yang dapat dilihat dalam Gambar 9, dimana bulan Agustus menjadi bulan dengan produksi energi listrik terbanyak dan bulan Februari menjadi bulan dengan produksi energi listrik paling rendah.

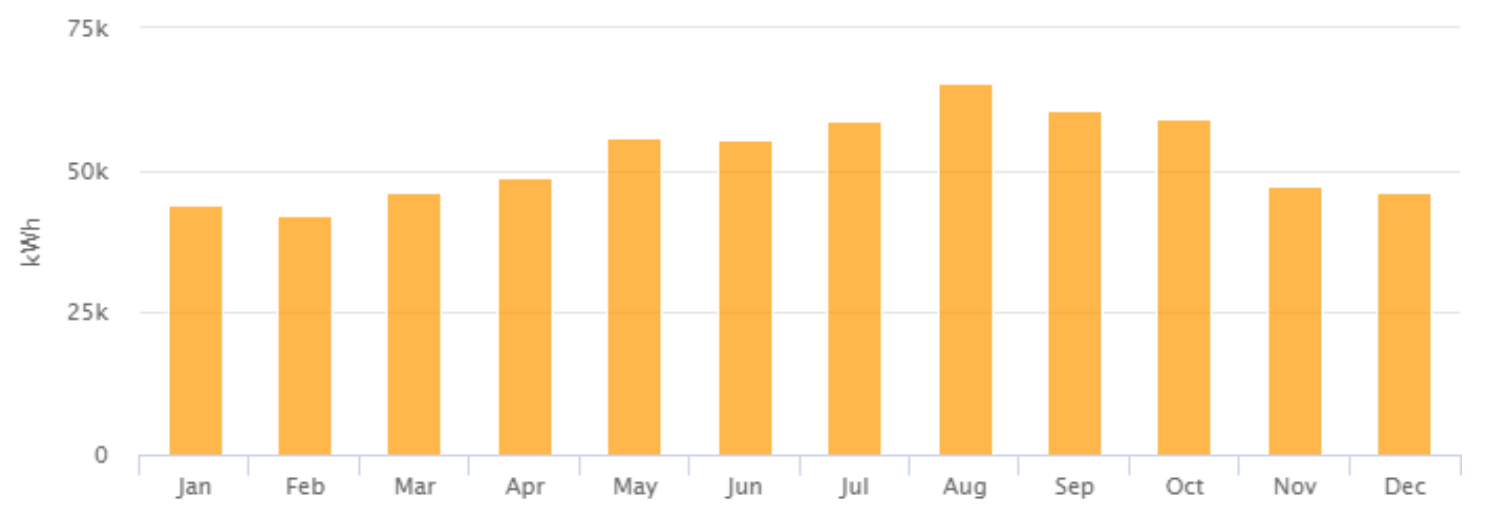

\section{Gambar 9. Hasil Simulasi Produksi Energi Listrik Bulanan PLTS Rooftop PT Pagilaran}

Grafik pada Gambar 9 dapat dirinci sebagai berikut dalam Tabel 6 GHI adalah Global Horizontal Irradiance atau jumlah total cahaya yang diterima oleh permukaan horizontal ke tanah tiap 1 $\mathrm{m}^{2}$, sedangkan POA adalah Plane of Array, yang merupakan kombinasi dari sinar matahari langsung, diffuse irradiance, dan iradiasi yang terpantulkan pada tanah tiap $1 \mathrm{~m}^{2}$. Berdasarkan Tabel 6, potensi energi listrik yang dapat dihasilkan dalam setahun adalah sebesar $629.840,80$ kWh, sehingga dapat memenuhi kebutuhan beban listrik di pabrik produksi dan pengolahan teh sebesar 95,85\%. Produksi energi listrik tertinggi terjadi pada bulan Agustus dengan hasil 
produksi energi listrik sebesar 65.515,9 kWh dan hasil produksi energi terendah berada pada bulan Februari sebesar 42.276,8 kWh. Nilai irradiance tertinggi juga terjadi pada bulan Agustus, sebesar $163 \mathrm{kWh} / \mathrm{m}^{2}$ setelah dikurangi rugi-rugi akibat efek shading. Selain itu dilakukan kalkulasi terkait Total Solar Resource Fraction atau TSRF, yaitu perbandingan antara tingkat produktivitas dari desain aktual dengan desain ideal pada lokasi yang ditentukan (Doyle, dkk, 2015). Rerata TSRF pada semua segmen atap adalah $97,7 \%$ dengan asumsi POA irradiance yang optimal adalah $1.593,5 \mathrm{kWh} / \mathrm{m}^{2}$ pada sudut kemiringan $16,2^{\circ}$ dan azimut $5^{\circ}$.

Tabel 6. Hasil Simulasi Electrical Power Monthly Production PLTS Rooftop PT Pagilaran

\begin{tabular}{|c|c|c|c|c|c|}
\hline Bulan & $\begin{array}{c}\mathbf{G H I} \\
\left(\mathbf{k W h} / \mathbf{m}^{\mathbf{2}}\right)\end{array}$ & $\begin{array}{c}\text { POA } \\
\left(\mathbf{k W h} / \mathbf{m}^{\mathbf{2}}\right)\end{array}$ & $\begin{array}{c}\text { Shaded } \\
\left(\mathbf{k W h} / \mathbf{m}^{\mathbf{2}}\right)\end{array}$ & $\begin{array}{c}\text { Nameplate } \\
\mathbf{( k W h )}\end{array}$ & $\begin{array}{c}\text { Grid } \\
(\mathbf{k W h})\end{array}$ \\
\hline Januari & 111,2 & 109,3 & 109,1 & $53.695,2$ & $44.098,5$ \\
\hline Februari & 104,6 & 103,6 & 103,4 & $50.812,3$ & $42.276,8$ \\
\hline Maret & 113,9 & 113,8 & 113,6 & $55.908,4$ & $46.043,2$ \\
\hline April & 119,9 & 120,4 & 120,2 & $59.201,6$ & $48.866,4$ \\
\hline Mei & 137,1 & 139,0 & 138,8 & $68.374,1$ & $55.824,1$ \\
\hline Juni & 133,8 & 136,2 & 136,0 & $66.867,8$ & $55.245,2$ \\
\hline Juli & 142,8 & 145,2 & 145,1 & $71.482,9$ & $58.603,4$ \\
\hline Agustus & 161,4 & 163,2 & 163,0 & $80.490,8$ & $65.515,9$ \\
\hline September & 151,0 & 151,1 & 150,9 & $74.518,0$ & $60.447,5$ \\
\hline Oktober & 148,6 & 147,7 & 147,5 & $72.732,2$ & $59.267,3$ \\
\hline November & 118,8 & 117,3 & 117,1 & $57.705,7$ & $47.293,3$ \\
\hline Desember & 114,6 & 113,1 & 112,9 & $55.392,3$ & $46.359,2$ \\
\hline Total & $\mathbf{1 . 5 5 7 , 7}$ & $\mathbf{1 5 5 9 , 9}$ & $\mathbf{1 5 5 7 , 6}$ & $\mathbf{7 6 7 . 1 8 1 , 3}$ & $\mathbf{6 2 9 . 8 4 0 , 8}$ \\
\hline
\end{tabular}

Temperatur lingkungan selama satu tahun disimulasikan berkisar pada rata-rata $26,6^{\circ} \mathrm{C}$ dengan menyadur data dari Weather Dataset TMY (Typical Meteorological Year) pada lokasi PT Pagilaran selama sepuluh tahun terakhir. Data tersebut sudah termasuk di dalam simulasi HelioScope. Kemudian, simulasi rerata temperatur modul surya selama satu tahun tersebut adalah sebesar $42,5^{\circ} \mathrm{C}$. Estimasi rugi-rugi yang pada simulasi desain sistem PLTS rooftop PT Pagilaran dapat dilihat pada Gambar 10.

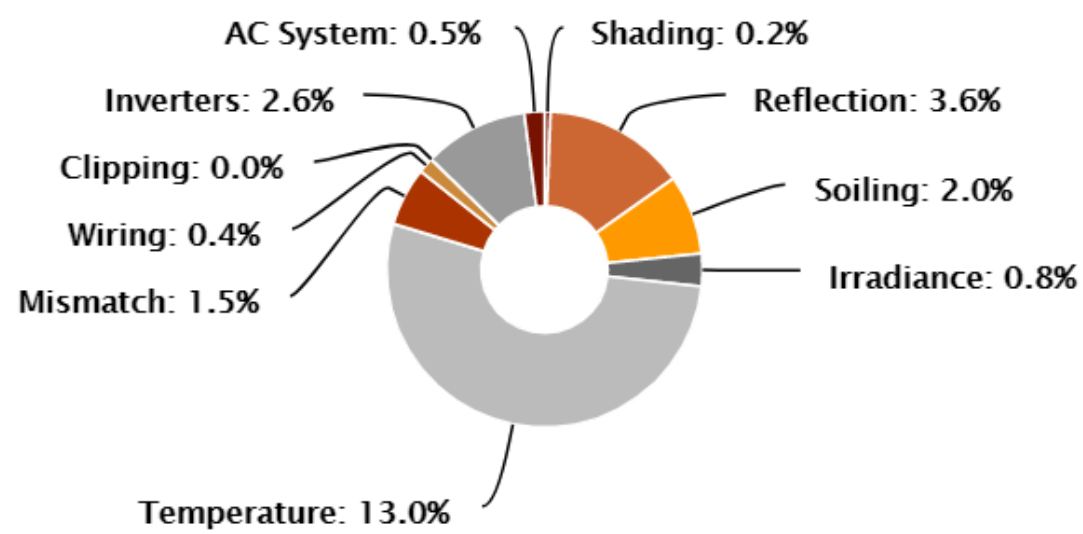

Gambar 10. Komposisi Rugi-rugi Daya pada PLTS Rooftop PT Pagilaran 
Rugi-rugi daya terbesar disebabkan oleh temperatur operasi modul surya sebesar $13 \%$, sedangkan rugi-rugi terkecil disebabkan oleh efek shading yaitu $0,2 \%$ dan clipping losses sebesar $0 \%$. Rugi-rugi ini dapat diminimalkan dikarenakan penyesuaian desain PLTS rooftop dengan kondisi aktual bangunan dan lingkungan sekitar, seperti cerobong pabrik, kondisi atap, dan pepohonan. Desain ILR yang telah memenuhi standar Folsom Labs, yaitu kurang dari 1,25 menyebabkan clipping losses dapat terminimalkan. Sehingga total energi listrik yang didapatkan melalui PLTS rooftop adalah sebesar $767.181,3 \mathrm{kWh} /$ tahun yang selanjutnya dikurangi dengan total rugi-rugi menjadi $629.840,8 \mathrm{kWh} /$ tahun. Selain itu, dilakukan simulasi performance ratio atau persentase total potensi energi dari PV array yang dapat dikonversikan menjadi energi listrik AC adalah sebesar 77,5\% dengan nilai kWh/kWp sebesar 1.209.

\section{KESIMPULAN}

Berdasarkan hasil simulasi yang telah dilakukan, estimasi total energi listrik yang dapat dihasilkan selama satu tahun oleh PLTS rooftop PT Pagilaran adalah sebesar 629.840,8 kWh. Angka ini mampu memenuhi kebutuhan beban listrik kawasan pabrik sebesar 95,85\%. Hasil simulasi irradiance dan produksi energi listrik terbesar terjadi pada bulan Agustus sebesar 163 $\mathrm{kWh} / \mathrm{m}^{2}$ dan $65.515,9 \mathrm{kWh}$. Rugi-rugi terbesar pada sistem PLTS rooftop PT Pagilaran disebabkan oleh temperatur operasi modul surya sebesar $13 \%$. Clipping losses dapat diminimalkan dengan menggunakan ILR sebesar 1,14 . Nilai $\mathrm{kWh} / \mathrm{kWp}$ atau total energi yang mampu dibangkitkan terhadap kapasitas PV array dalam setahun didapatkan sebesar 1.209. Hasil simulasi menunjukkan rasio kinerja adalah sebesar 77,5\%. Nilai TSRF didapatkan 97,7\% dengan asumsi POA irradiance optimal. Saran untuk penelitian lanjutan adalah peminimalan potensi total rugi-rugi, sehingga rasio kinerja menjadi lebih baik. Selain itu, dapat dilakukan penelitian lanjutan lainnya dengan mempertimbangkan analisis tekno-ekonomi sebagai bahan studi kelayakan pemasangan PLTS rooftop apabila ditinjau dari segi investasi dan finansial.

\section{DAFTAR RUJUKAN}

Ariani, W. D., \& Winardi, B. (2014). Analisis Kapasitas dan Biaya Pembangkit Listrik Tenaga Surya (PLTS) Komunal Desa Kaliwungu, Kabupaten Banjarnegara. Transient, 3(2), $158-165$.

Arinaldo, D., Mursanti, E., \& Tumiwa, F. (2019). Implikasi Paris Agreement terhadap Masa Depan Pembangkit Listrik Tenaga Uap (PLTU) Batubara di Indonesia. IESR: Accelerating Low-Carbon Energy Transtion, 12.

Aspriadi, F., Sulaiman, M., \& Wilopo, W. (2019). Perancangan Energi Pembangkit Listrik Tenaga Mikrohidro di Kawasan Perkebunan Teh PT. Pagilaran Batang, Jawa Tengah. Jurnal Otomasi, Kontrol, dan Instrumentasi, 11, 13.

Dewan Energi Nasional. (2020). Buku Bauran Energi Nasional 2020. Sekretariat Jenderal DEN.

Doyle, C., Truitt, A., Inda, D., Lawrence, R., Lockhart, R., \& Golden, M. (2015). SAPC Best Practices in PV System Installation. National Renewable Energy Laboratory (NREL), 36. Folsom Labs. (2016). A Deep-Dive into the Top Three PV Design Optimization Trends: SPI Grana Design Optimization by Folsom. 
Hernández-Callejo, L., Gallardo-Saavedra, S., \& Alonso-Gómez, V. (2019). A Review of Photovoltaic Systems: Design, Operation and Maintenance. Solar Energy, 188, 426440. https://doi.org/10.1016/j.solener.2019.06.017

Ilyas, S., \& Kasim, I. (2017). Peningkatan Efisiensi Pembangkit Listrik Tenaga Surya dengan Reflektor Parabola. JETri, 14, 67-80.

NASA, National Aeronautics and Space Administration. (2021, May 3). Power | Data Access Viewer. Retrieved from www.power.larc.nasa.gov/data-access-viewer

Pandey, S., Kumar, R., \& Panwar, K. (2019). Calculation of Inverter Power Clipping Loss due to PV Array Oversizing. International Journal of Electrical Engineering and Technology, 10(4). https://doi.org/10.34218/IJEET.10.4.2019.005

QuickMount PV. (2020). Rail Mounting System: Installation Manual. QRail System Rev. 7.

Rizkasari, D., Wilopo, W., \& Ridwan, M. K. (2020). Potensi Pemanfaatan Atap Gedung untuk PLTS di Kantor Dinas Pekerjaan Umum, Perumahan dan Energi Sumber Daya Mineral (PUP-ESDM), Provinsi Daerah Istimewa Yogyakarta. Journal of Approriate Technology for Community Services, 1(2), 104-112. https://doi.org/10.20885/jattec.vol1.iss2.art7

SMA. (2018). Sunny Tripower: The Ultimate Solution for Decentralized PV Plant 12000TL-US / 15000TL-US / 20000TL-US / 24000TL-US / 30000TL-US. SMA Solar Technology AG, 2.

Umar, N., Bora, B., Banerjee, C., \& Panwar, B. S. (2018). Comparison of Different PV Power Simulation Softwares: Case Study on Performance Analysis of $1 \mathrm{MW}$ Grid-Connected PV Solar Power Plant. International Journal of Engineering Science Invention (IJESI), ス7), 14.

Wicaksena, A. G., \& Winardi, B. (2017). Analisis Pengaruh Perubahan Temperatur dan Irradiasi pada Tegangan, Arus, dan Daya Keluaran PLTS Terhubung Grid 380 V. Transient, 6(2), 202-208.

Wijoyo, Y. S., \& Halim, A. F. (2018). Analisis Pemasangan Rooftop Photovoltaic System pada Sistem Elektrikal Bangunan. CITEE 2018, 6.

Winardi, B., Nugroho, A., \& Dolphina, E. (2019). Perencanaan Dan Analisis Ekonomi Pembangkit Listrik Tenaga Surya (PLTS) Terpusat Untuk Desa Mandiri. Jurnal Tekno, 16(2), 1-11. https://doi.org/10.33557/jtekno.v16i1.603

Yakin, K., \& Rajagukguk, A. (2020). Desain Pembangkit Listrik Tenaga Surya Tipe Rooftop on Grid-Sistem pada Gedung Laboratorium Teknik Elektro Universitas Riau. Jom FTEKNIK, 7, 11. 